\title{
Rasa Bersalah dan Strategi Koping Pada Petugas Kepolisian yang Menghilangkan Nyawa Orang Lain Saat Sedang Bertugas
}

\author{
Ida Ayu Kencana Jalatri Samgara Putri dan David Hizkia Tobing \\ Program Studi Psikologi, Fakultas Kedokteran, Universitas Udayana \\ davidhizkia@yahoo.com
}

\begin{abstract}
Abstrak
Menurut Peraturan Kepala Kepolisian Negara RI Nomor 1 Tahun 2009, bahwa petugas kepolisian dalam melaksanakan tugas di lapangan diberikan wewenang untuk dapat menggunakan senjata yang berfungsi untuk menjaga keselamatan dari ancaman musuh termasuk melakukan tindakan pembunuhan sehingga dapat menghilangkan nyawa orang lain saat sedang bertugas. Tindakan menghilangkan nyawa orang lain tidak sesuai dengan sistem nilai-nilai dan norma yang ada pada masyarakat dan akan menimbulkan berbagai perasaan, salah satunya adalah rasa bersalah. Rasa bersalah akan membebani petugas kepolisian yang menghilangkan nyawa orang lain jika tidak dapat diatasi dengan baik. Maka dari itu dibutuhkan adanya strategi koping dalam diri individu terhadap apa yang dialami. Penelitian ini bertujuan untuk mengetahui rasa bersalah yang dialami pada petugas kepolisian, perasaan yang dapat memengaruhi petugas kepolisian, serta strategi koping yang digunakan petugas kepolisian setelah menghilangkan nyawa orang lain. Subjek dalam penelitian ini adalah tiga orang petugas kepolisian yang memiliki pengalaman menghilangkan nyawa orang lain saat sedang bertugas.

Penelitian ini menggunakan metode penelitian kualitatif dengan pendekatan studi kasus. Penelitian ini menghasilkan temuan utama yaitu, rasa bersalah yang berupa reaksi psikis seperti mimpi serta trauma dan strategi koping cenderung berorientasi pada emosi seperti menjalankan kewajiban, perilaku menghindar, mendekatkan diri kepada Tuhan, serta strategi koping cenderung berorientasi pada masalah seperti pemindahan tempat dalam bertugas.
\end{abstract}

Kata Kunci: Menghilangkan Nyawa Orang Lain, Rasa Bersalah, Strategi Koping.

\begin{abstract}
According to the Regulation of the Police Chief of the Republic of Indonesia Number 1 year 2009, the police officers in performing their duties makes it possible to use weapons that can be used to keep safety from enemies menace include murder so it can be kill the lives of others while on duty. Killing the lives of others does not suit to the system of values and norms that exist in the community will create various feeling, one of is the guilt feeling. Guilt feeling will overwhelm the police officer who takes the life of another person if it cannot be handled properly. Therefore it is necessary to individual have coping strategies to resolve what they felt. This study aims to find out the opposite of existing feelings on police officers, feelings that can affect police officers, and coping strategies that can be used to police officers after take the life of others. Subject in this study are three police officers who have experience taking others live while on duty.

This research used qualitative research method with case study approach. This study resulted the main findings that guilt feeling in form as psychic reactions such as dreams and trauma, and coping strategies of emotion focused coping such as carrying out obligations, avoidance behavior, seeking meaning, and coping strategies of problem focused coping such as moving places on duty.
\end{abstract}

Keywords: Killing The Lives of Others, Guilt Feeling, Coping Strategy. 


\section{LATAR BELAKANG}

Indonesia merupakan negara yang memiliki populasi penduduk yang cukup tinggi dengan jumlah penduduk dari tahun ke tahun yang terus meningkat. Data Badan Kependudukan dan Keluarga Berencana Nasional (BKKBN) menjelaskan, laju pertumbuhan manusia Indonesia saat ini mencapai 1,49 persen setiap tahun dari jumlah penduduk Indonesia (Kompas, 2012). Meningkatnya jumlah penduduk tersebut membuat kebutuhan individu meningkat pada suatu pekerjaan. Pekerjaan merupakan suatu tuntutan hidup yang sudah menjadi bagian dalam diri individu itu sendiri. Berbagai pekerjaan dilakukan untuk dapat memenuhi kebutuhan hidup sehari-hari. Beberapa pekerjaan menuntut indivdu untuk melakukan pekerjaan yang melibatkan perasaan secara emosional pada pekerjanya. Pekerjaan yang melibatkan perasaan tersebut salah satunya terkait dengan menghilangkan nyawa orang lain. Salah satu pekerjaan yang melibatkan pekerjanya untuk menghilangkan nyawa orang lain ketika bertugas yaitu menjadi seorang petugas kepolisian.

Petugas kepolisian merupakan salah satu lembaga penegak hukum yang dibentuk untuk menjalankan tugas dan fungsi dalam memelihara masyarakat. Kepolisian memiliki peranan dalam pemeliharaan keamanan dan ketertiban masyarakat, penegakan hukum, perlindungan dan pelayanan kepada masyarakat (Undang-undang Nomor 2 tentang Kepolisian Negara RI Tahun 2002). Penugasan yang diberikan kepada pihak kepolisian dalam menjaga keamanan sangat berhubungan dengan risiko tinggi yang memungkinkan petugas kepolisian mengalami ancaman maupun membahayakan bagi keselamatan jiwa di lapangan. Hal tersebut disertai tahapan dalam penggunaan kekuatan yang melibatkan petugas kepolisian sepeti yang tertera dalam Peraturan Kepala Kepolisian Negara RI Nomor 1 pasal 9 terdiri dari tahap pencegahan, perintah lisan, kendali tangan kosong lunak, kendali tangan kosong keras, kendali senjata tumpul, dan kendali dengan menggunakan senjata api atau alat lain yang dapat menghentikan tindakan maupun perilaku pelaku kejahatan atau tersangka yang dapat menyebabkan luka parah hingga kematian anggota Polri atau masyarakat (Peraturan Kepala Kepolisian Negara RI Nomor 1 Tahun 2009).

Sehubungan dengan hal itu, terdapat beberapa kasus terkait dengan anggota kepolisian yang menggunakan wewenangnya dalam menggunakan senjata yang menyebabkan hilangnya nyawa orang lain ketika menjalankan tugas di lapangan khususnya di Indonesia, terdapat seorang polisi yang menghilangkan nyawa seseorang saat sedang bertugas yakni seorang pria berinisial W. W merupakan seorang anggota kepolisian yang bertugas di Reskrimum Jatanras Polda Bali. W merupakan seorang anggota polisi yang pernah menghilangkan nyawa seseorang saat $\mathrm{W}$ bertugas. $\mathrm{W}$ yang bertugas sebagai anggota tim Buser (Buru Sergap) bersama 6 orang rekannya memburu beberapa pelaku perampokan nasabah bank. Pelaku perampokan yang membawa senjata dan mengancam $\mathrm{W}$ serta rekannya, kemudian dilumpuhkan dan ditembak mati. Setelah penembakan terjadi, W merasa dihantui oleh pikiran yang tidak tenang dan selalu terbayang wajah pelaku yang W tembak (Studi Pendahuluan, 2017).
Berdasarkan uraian diatas, dapat dikatakan bahwa terdapat risiko atau dampak yang akan ditanggung oleh pihak kepolisian yang menghilangkan nyawa seseorang saat menjalankan tugas. Pada hakikatnya individu mengetahui bahwa menghilangkan nyawa orang lain merupakan pelanggaran pada sistem nilai-nilai norma yang ada pada masyarakat dan akan menimbulkan berbagai perasaan seperti, rasa takut, rasa sedih, rasa cemas yang membayang-bayangi khususnya rasa bersalah yang akan ditanggung seumur hidup. Rasa bersalah dapat menutup diri dari kebenaran, membuat individu menipu diri sendiri, dan menyebabkan agresif secara berlebihan dalam usaha untuk mempertahankan diri dari serangan yang dilakukan sendiri, mungkin mencoba menghindar dari akibat perbuatan salah kepada orang lain (Coleman, 1992). Bagi seseorang yang menghilangkan nyawa orang lain saat melakukan tugas, rasa bersalah tentunya dapat membayangi ketika menghilangkan nyawa orang lain. Hal tersebut akan membebani bagi seseorang yang menghilangkan nyawa orang lain dan jika tidak dapat diatasi dengan baik, tentu akan berpotensi menimbulkan masalah baru yang akan mengganggu aktivitas individu. Maka dari itu dibutuhkan adanya strategi koping dalam diri individu terhadap apa yang dialami oleh individu tersebut.

Menurut Gowan (dalam Taylor, 2012) dalam koping terdapat strategi koping yang didefinisikan sebagai upaya yang dilakukan oleh individu untuk mengelola tuntutan eksternal dan internal yang dihasilkan dari sumber stres. Lazarus \& Folkman (dalam Taylor, 2012) membagi strategi koping menjadi dua bentuk, yaitu koping yang berorientasi pada masalah (problem focused coping) dan koping yang berorientasi pada emosi (emotion focused coping). Bentukbentuk koping tersebut biasa digunakan sesuai dengan permasalahan yang dialami oleh masing-masing individu terkait dengan perasaan yang dihadapi khususnya bagi seseorang yang menghilangkan nyawa orang lain saat bertugas.

Berdasarkan pemaparan diatas, hal inilah yang menjadi latar belakang penelitian dalam mengambil tema ini. Hal ini merupakan hal yang menarik untuk melihat perasaan yang dialami petugas kepolisian yang menghilangkan nyawa orang lain dalam melaksanakan tugas yang diberikan serta bagaimana permasalahan tersebut dapat ditangani, khususnya rasa bersalah dan strategi koping pada petugas kepolisian. Pada penelitian ini akan dibahas apakah terdapat rasa bersalah pada petugas kepolisian yang timbul ketika menghilangkan nyawa orang lain, strategi koping apa yang digunakan pada petugas kepolisian setelah menghilangkan nyawa orang lain saat sedang bertugas, dan bagaimana rasa bersalah tersebut memengaruhi petugas kepolisian setelah proses menghilangkan nyawa orang lain.

\section{METODE PENELITIAN}

\section{Tipe Penelitian}

Penelitian ini menggunakan metode penelitian kualitatif dengan pendekatan studi kasus. Penelitian dengan desain studi kasus dilakukan dengan cara observasi secara mendalam terhadap suatu obyek penelitian yang dipilih dari beberapa keadaan yang dianggapnya sama (Subiyanto, 1993). Pada penelitian ini menggunakan proses penelitian multiple case, 
yang pada dasarnya penelitian studi kasus jamak (multiplecase) merupakan penelitian yang menggunakan lebih dari satu kasus. Melalui pendekatan studi kasus jamak (multiple-case), diharapkan dalam penelitian ini dapat pemahaman terkait dengan pengalaman yang dialami oleh subjek dan bagaimana subjek dapat memaknai, sehingga dapat memberikan gambaran makna pengalaman dari subjek terkait dengan kasus yang akan diteliti, mengenai rasa bersalah dan strategi koping pada petugas kepolisian yang menghilangkan nyawa orang lain saat sedang bertugas.

Penelitian ini menggunakan unit analisis individu yaitu anggota kepolisian di Polda Bali yang pernah memiliki pengalaman dalam menghilangkan nyawa orang lain saat sedang bertugas. Teknik sampling yang digunakan dalam penelitian ini adalah purposive sampling. Pada penelitian ini, Subjek utama yang dipilih merupakan petugas kepolisian yang pernah memiliki pengalaman menghilangkan nyawa orang lain dengan rentang usia (21-60 tahun). Penelitian ini berfokus dalam meneliti individu yang menjadi petugas kepolisian yang berdomisili di Bali agar memudahkan proses penggalian data. Data yang diperoleh melalui hasil wawancara berupa rekaman audio akan diubah dalam bentuk verbatim dengan format dokumen dengan mengetik setiap kata yang terdengar dari rekaman audio, hasil observasi yang berupa tulisan juga akan diubah dalam bentuk teks dengan format dokumen. Analisis data dibagi menjadi tiga, yaitu data reduction (reduksi data), data display (penyajian data), dan conclusion drawing/verification (penarikan kesimpulan atau verifikasi) (Sugiyono, 2013). Teknik analisis data selanjutnya yang dilakukan dalam penelitian ini adalah teknik coding yang dibagi menjadi tiga bagian yaitu open coding, axial coding dan selective coding. Pada penelitian ini, uji kredibilitas data dilakukan dengan metode perpanjangan pengamatan, peningkatan ketekunan, triangulasi, analisis kasus negatif, dan bahan referensi.

Data penelitian dilakukan dengan pemberian informed consent ini bertujuan untuk mengantisipasi terjadinya konsekuensi negatif dalam penelitian atau mencegah adanya perlakuanperlakuan yang dirahasiakan yang dapat merugikan subjek. Responden yang telah menyetujui informed consent tersebut kemudian memiliki tanggung jawab etis untuk memberikan informasi sejelas-jelasnya dan sebenar-benarnya sepanjang informasi tersebut tidak mengganggu privasi serta tidak berisiko menciderai subjek penelitian, baik secara fisik maupun secara sosial serta ketidaknyamanan secara psikologis.

\section{Lokasi Penelitian}

Lokasi pengambilan data dalam penelitian, khususnya melibatkan ketiga subjek dilakukan di Bali yaitu di Polda Bali dan Polres Klungkung Bali. Lokasi untuk pengambilan data kedua subjek dilakukan di Polda Bali dikarenakan subjek pertama dan kedua merupakan anggota kepolisian yang sedang bertugas di Polda Bali dan berdomisili di Denpasar, sedangkan subjek ketiga merupakan anggota kepolisian yang sedang bertugas di Polres Klungkung dan berdomsili di Klungkung.

\section{Pengumpulan Data}

\section{Pre-eliminary Study}

Tahap awal pengumpulan data dilakukan dengan pelaksanaan pre-eliminary study yang dilakukan peneliti dengan mewawancarai satu petugas kepolisian yang bertugas di Reskrimum Polda Bali terkait rasa bersalah menghilangkan nyawa orang lain saat bertugas dan bagaimana strategi koping yang diterapkan pada subjek.

\section{Pengumpulan Data dengan Wawancara dan Observasi}

Penelitian ini kemudian dilanjutkan dengan melakukan proses wawancara secara mendalam terhadap subjek. Penelitian ini menggunakan teknik wawancara semi terstruktur dilanjutkan dengan proses wawancara yang tidak berjalan kaku hanya berdasarkan guideline untuk mendapatkan data serta informasi yang lebih mendalam. penelitian ini diperkuat data dengan melakukan observasi. Observasi dilakukan pada subjek dengan teknik pencatatan secara deskriptif selama wawancara berlangsung dan pencatatan terhadap respon nonverbal subjek dalam menanggapi pertanyaan yang diajukan. Observasi berlangsung pada lokasi tempat dan hari yang sama dengan pelaksanaan wawancara. Secara spesifik, hal yang diamati dalam observasi mencakup respon nonverbal yang tercermin dalam perilaku, sikap, serta ekspresi yang ditampilkan subjek selama wawancara berlangsung. Hasil observasi tersebut kemudian dituangkan dalam bentuk catatan lapangan atau fieldnote dan digunakan sebagai data pendukung hasil wawancara.

\section{Analisis Data}

\section{$\underline{\text { Reduksi Data }}$}

Tahap pertama dalam reduksi adalah dengan melakukan open coding. Tahap selanjutnya, hubungan dari kategori-kategori teks yang telah disusun sebelumnya dilihat lalu dikumpulkan dengan kategori-kategori yang saling berkaitan. Tahap terakhir dalam reduksi data adalah selective coding, yaitu memili kategori-kategori yang memiliki kaitan dan sesuai dengan fokus dalam penelitian.

Penyajian Data

Data dalam penelitian ini disajikan dalam bentuk tabel yang berisi hasil pengumpulan data dari kedua subjek dan telah disusun sesuai dengan si kategori-kategori yang saling berkaitan.

Penarikan Kesimpulan atau Verifikasi

Penarikan kesimpulan kemudian dilakukan setelah menyelesaikan hasil penelitian dan pembahasan yang berupa narasi maupun yang disajikan dalam bentuk tabel-tabel.

\section{HASIL PENELITIAN}

Penelitian ini menggunakan tiga subjek yang berprofesi sebagai anggota polisi, namun subjek pertama dan subjek kedua tidak memiliki rasa bersalah, sedangkan subjek ketiga memiliki rasa bersalah terkait menghilangkan nyawa orang lain saat bertugas. Hasil penelitian akan dipaparkan berdasarkan lima tema yakni, identitas subjek, proses kejadian, pasca kejadian, rasa bersalah, dan strategi koping. 


\section{Tema 1: Identitas Subjek}

\section{Subjek Pertama (Y)}

Subjek pertama yaitu $\mathrm{Y}$ merupakan seorang anggota kepolisian yang berusia 40 tahun. Y merupakan anggota kepolisian yang sedang bertugas di Polda Bali sebagai anggota Subdit (Sub Direktorat) Tiga Unit Jatanras (Kejahatan dan Kekerasan) Ditreskrim (Direktur Reserse dan Kriminal). Pendidikan terakhir yang pernah ditempuh oleh Y adalah S1 Hukum. Y bertugas di Aceh untuk pertama kali selama sebelas bulan, kemudian yang kedua selama tujuh bulan, dan ketiga selama tujuh bulan. Saat di Aceh, Y ditempatkan di Satuan Pemukul Polri (Kepolisian Republik Indonesia) dalam Operasi Rencong yang khusus menangani para pemberontak. Saat bertugas di Aceh, Y ditempatkan di Aceh bagian Utara yang sesuai dengan prosedur SOP (Standard Operating Procedures) Kepolisian melalui Diskresi Kepolisian.

\section{Subjek Kedua (X)}

Subjek kedua yaitu X merupakan seorang anggota kepolisian yang berusia 37 tahun. X merupakan anggota kepolisian yang sedang bertugas di Polda Bali sebagai anggota dibagian penyidikan. Pada pelaksanaan tugasnya, X pernah bertugas sebelumnya di Ambon sebagai anggota kesatuan Brimob di Mako (Markas Komando) Brimob Paso. Pada tahun 2004, X dimutasi ke Polda Bali hingga sekarang. Melalui Sprint (Surat Perintah) dari kepolisian, X ditempatkan di Ambon Maluku dari tanggal 1 sampai 31 Agustus 2001 untuk melakukan penjagaan dan pengawalan di Mako Brimob Paso.

\section{Subjek Ketiga (Z)}

Subjek ketiga yaitu $\mathrm{Z}$ merupakan seorang anggota kepolisian yang berusia 37 tahun. $Z$ merupakan anggota kepolisian yang sedang bertugas di Polres Klungkung Bali sebagai anggota kepolisian dibagian Satlantas (Satuan Lalu Lintas) Polres Klungkung. $Z$ mengikuti pendidikan sebagai anggota kepolisian dan terpilih sebagai anggota Tim Anti-sniper yang merupakan anggota untuk mengantisipasi sniper-sniper gelap yang ingin memperkeruh suasana. Pada tahun 2002, Z ditugaskan untuk menemani Kapolres (Kepala Kepolisian Resor) Maluku sampai Kapolres Maluku pindah ke Makasar, $\mathrm{Z}$ pun memutuskan untuk dipindahtugaskan ke Bali.

\section{Tema 2: Proses Kejadian}

\section{Latar Belakang Penembakan}

\section{Penghadangan di Jalan}

Latar belakang penembakan pertama yaitu penghadangan di jalan yang dialami oleh subjek pertama (Y) yang merupakan seorang anggota kepolisian yang ditugaskan di Aceh bagian Utara untuk menangani para separatis. Latar belakang penembakan dialami oleh subjek Y terjadi pada siang hari dalam situasi subjek mengalami penyerangan saat berada diperjalanan oleh sekelompok separatis bersama anggota lainnya yang ditugaskan untuk menjaga wilayah. Subjek Y yang sedang bertugas menjaga wilayah bertemu dengan sekolompok separatis yang menghadang subjek bersama rekan-rekannya.

\section{Pengepungan di Tengah Laut}

Latar belakang penembakan kedua yaitu pengepungan di tengah laut yang dialami oleh subjek kedua (X) seorang anggota kepolisian yang ditugaskan untuk mengawal speedboat yang berisikan warga Ambon, Maluku. Ketika subjek X mengawal speedboat, terjadi penghadangan atau pengepungan di tengah laut oleh empat speedboat yang mencoba untuk menghalangi jalan dari speedboat yang dikawal subjek X menuju Pulau Kairatu.

Penyergapan di Perkampungan

Latar belakang penembakan ketiga yaitu penyergapan di perkampungan yang dialami oleh subjek ketiga $(Z)$ seorang anggota kepolisian yang ditugaskan sebagai anggota Tim Anti-sniper untuk mengantisipasi sniper-sniper gelap di Ambon, Maluku. Ketika subjek $Z$ bertugas untuk mencari para sniper-sniper gelap, terdapat kelompok tertentu yang membuat keributan di perkampungan kebun cengkeh, subjek beserta anggota lainnya terpancing oleh sekelompok provokator yang membuat subjek keluar dari tempat persembunyian kemudian kelompok tersebut melakukan penyergapan kepada subjek beserta rekan-rekannya sehingga subjek terjebak selama seminggu. Subjek Z terkunci bersama anggota lain selama seminggu dan tidak dapat keluar.

Pemicu Terjadinya Penembakan

Perasaan Terancam

Pemicu penembakan yang terjadi salah satunya karena adanya perasaan terancam yang dialami oleh ketiga subjek. Subjek Y yang melihat beberapa rekannya yang meninggal telah terpotong-potong bagian tubuhnya beberapa hari sebelum subjek Y bertemu dengan musuh yang menghadangnya di jalan, hal tersebut memicu subjek untuk melakukan penembakan terhadap musuh yang melakukan perlawanan serta mengancam jiwa petugas kepolisian. Perasaan terancam juga dialami oleh subjek $X$, kesulitan yang dialami subjek $X$ untuk meminta bantuan di tengah laut membuat subjek merasa terancam dan penuh tekanan selain itu subjek berpikir bahwa dirinya juga harus memperhitungkan peluru yang dikeluarkan untuk menembak apabila musuh mendekat. Pada subjek $\mathrm{Z}$ juga mengalami perasaan terancam ketika subjek sedang bertugas di Ambon untuk mengawasi sekelompok sniper liar yang membuat kekacauan di perkampungan, subjek $\mathrm{Z}$ beserta rekan-rekannya mengalami penyergapan oleh kelompok tersebut.

Perlawanan

Perlawanan menjadi salah satu faktor pemicu terjadinya penembakan yang dialami oleh ketiga subjek. Ketiga subjek yaitu Y, X, dan Z berpikir untuk melepaskan tembakan kepada musuhnya dikarenakan musuh dari ketiga subjek tersebut melakukan suatu perlawanan yang mengancam nyawa subjek. Pada subjek Y yang merasa jiwanya terancam akhirnya melakukan perlawanan dengan mengejar kelompok separatis tersebut, namun kelompok tersebut juga melakukan perlawanan dengan menembaki para anggota kepolisian yang mengejarnya. Perlawanan juga terjadi ketika subjek $\mathrm{X}$ mengalami pengepungan di tengah laut. Subjek $X$ yang bertugas mengawal warga, dikepung oleh musuh di tengah laut dan menembaki speedboat yang $X$ tumpangi. Begitu juga dengan subjek $Z$ yang terjebak dalam perkampungan, terkunci selama seminggu bersama rekan-rekannya. Perlawanan musuh yang membuat nyawa subjek beserta rekannya terancam, memicu subjek untuk melakukan perlawanan balik kepada musuh dengan menembak musuh tersebut.

Balas Dendam

Balas dendam juga merupakan salah satu faktor pemicu terjadinya penembakan. Ketiga subjek memiliki rasa ingin membalaskan dendam terhadap tindakan yang telah dilakukan 
musuh. Beberapa rekan subjek $\mathrm{Y}$ sebelumnya ketika melakukan pengawasan wilayah tertangkap oleh kelompok tersebut dan rekannya dibunuh secara sadis. Kesadisan dari kelompok separatis tersebut membuat subjek Y dipenuhi oleh perasaan dendam dan amarah terhadap musuh, subjek menganggap bahwa kelompok tersebut layak untuk mati apabila subjek bertemu dengan kelompok tersebut. Subjek X yang bertugas mengawal warga juga mengalami tekanan dan ketegangan, terdapat beberapa warga yang terkena tembakan dari musuh serta supir yang mengemudikan speedboat juga terkena tembakan dari musuh membuat $\mathrm{X}$ merasa tertekan serta dendam kepada musuh yang telah membuatnya berada dalam situasi tersebut. Pada subjek $Z$ yang melihat rekannya terbunuh dihadapannya membuat $Z$ diliputi oleh perasaan dendam. $Z$ pun merasa sedih sekaligus marah melihat teman seperjuangannya yang selalu menemaninya jatuh terkena tembakan dihadapannya sendiri.

\section{$\underline{\text { Korban Penembakan }}$}

\section{Separatis GAM (Gerakan Aceh Merdeka)}

Separatis GAM (Gerakan Aceh Merdeka) merupakan korban dari subjek Y yang berjumlah empat orang. Kelompok tersebut melakukan penghadangan di jalan terhadap subjek beserta anggota kepolisian lainnya saat bertugas untuk menjaga wilayah.

\section{Warga Suku Tertentu}

Korban selanjutnya yaitu warga suku tertentu yang berada di Ambon. Korban merupakan beberapa warga yang dihadapi oleh subjek X yaitu beberapa warga sipil serta dua orang yang merupakan anggota TNI (Tentara Nasional Indonesia) dan Polri (Kepolisian Republik Indonesia). Korban dari anggota Polri merupakan anggota Brimob yang ditugaskan bersama dengan subjek untuk mengawal namun korban berkhianat untuk menyerang warga dan subjek $X$ yang berada dalam speedboat.

\section{Kelompok Sniper Liar}

Kelompok sniper liar merupakan korban dari subjek $\mathrm{Z}$ yang ingin memprovokasi keadaan di perkampungan. Korban merupakan orang-orang yang ingin mengacaukan Ambon.

\section{Kondisi Saat Penembakan}

\section{Terkekang dan Penuh Tekanan}

Pada kondisi terkekang ini dialami oleh ketiga subjek seperti kondisi pada subjek. Y yang merasa terkekang karena subjek menganggap bahwa suasana yang penuh ketegangan di daerah konflik membuat subjek tidak merasa nyaman, selain itu subjek juga merasa tertekan karena subjek merasa jiwanya selalu terancam sehingga subjek waspada setiap saat. Pada subjek X yang mengalami peperangan ditengah laut, membuat $\mathrm{X}$ merasakan keadaan yang menekan dirinya untuk mengambil tindakan yang cepat dalam menyelamatkan warga dan jiwanya sendiri serta terukur untuk mengeluarkan tembakan terhadap para musuh. Perang di tengah laut juga membuat subjek merasakan ketegangan karena $\mathrm{X}$ berpikir sulit untuk dirinya berlindung saat di tengah laut. Begitu juga yang dialami oleh subjek $\mathrm{Z}$ yang disergap dan terkunci selama satu minggu, melihat beberapa teman yang meninggal dihadapannya serta banyak anggota tubuh korban yang berserakan. Subjek Z merasakan penuh tekanan setiap saat dikarenakan $Z$ harus bertahan hidup dengan kondisi yang penuh dengan kekacauan.

\section{Situasi dan Kondisi yang Menegangkan}

Ketika penembakan terjadi, situasi dan kondisi yang sangat menegangkan dialami oleh ketiga subjek yang berusaha untuk mempertahankan nyawanya. Ketiga subjek dituntut untuk cepat dalam mengambil tindakan untuk melindungi dirinya dan masyarakat. Pada subjek Y dengan situasi dan kondisi yang mencekam karena subjek harus mempersiapkan mental apabila bertemu musuh dan menyerangnya secara tiba-tiba. Subjek berhasil menghindari beberapa tembakan yang musuh keluarkan dan melakukan perlawanan kepada musuh sehingga terjadi tembak-menembak antara subjek dengan pihak musuh. Subjek $X$ juga mengalami situasi dan kondisi yang menegangkan serta mencekam karena selain subjek $\mathrm{X}$ juga harus melindungi dirinya dan warga yang dikawal, $\mathrm{X}$ juga harus memikirkan strategi yang tepat dan cepat untuk melawan musuh. Situasi menegangkan juga dialami oleh subjek Z. Subjek Z yang sedang melaksanakan tugasnya harus berhadapan dengan kelompok sniper liar dan memancing subjek keluar dari persembunyiannya sehingga membuat subjek bersama rekan-rekannya terjebak di dalam perkampungan.

HAM (Hak Asasi Manusia) Tidak Berlaku

Pada kondisi tersebut, subjek Y dan X menyebutkan bahwa tidak ada HAM (Hak Asasi Manusia) yang berlaku di daerah konflik. Kondisi dan situasi yang menegangkan membuat HAM tidak dapat berlaku di daerah konflik.

\section{Tema 3: Pasca Kejadian}

\section{$\underline{\text { Reaksi Subjek }}$}

\section{Reaksi Fisik}

Adanya reaksi fisik yang dialami oleh kedua subjek yaitu subjek $X$ dan subjek $Z$ yang mengganggu kedua subjek tersebut setelah proses penembakan terjadi. Reaksi fisik yang dialami kedua subjek seperti telinga yang berdenging serta kurangnya konsentrasi pada subjek $\mathrm{X}$ dan subjek $\mathrm{Z}$ yang juga mengalami reaksi fisik yang membuat subjek tidak menginginkan tubuhnya untuk disentuh oleh orang lain. Hal tersebut terjadi ketika subjek bersama rekannya bahwa dirinya akan selalu waspada dan terkejut ingin membunuh orang tersebut apabila ada yang menyentuh dirinya.

Reaksi Psikis

Reaksi psikis dialami oleh ketiga subjek seperti perasaan emosi, luapan perasaan jengkel, perasaan bangga, perasaan ingin membantai, menganggap bahwa menghilangkan nyawa merupakan hal yang biasa, perasaan benci terhadap pelaku, takut akan dibunuh, serta membalas dendam dan mempertahankan diri.

\section{$\underline{\text { Kondisi Subjek Setelah Penembakan }}$ \\ Mimpi}

Subjek Z merasa bahwa korban pernah mencarinya dalam mimpi. Mimpi tersebut dirasa sangat nyata sehingga subjek merasa ketakutan ketika akan mengawali tidur. Mimpi akan kematian serta korban yang menghampirinya kerap menghantui subjek ketika subjek tidur.

Kaget

Salah satu subjek yaitu $\mathrm{Z}$ memiliki reaksi tubuh yang mudah terkejut apabila ada yang menyentuh dirinya seperti rekannya yang mencoba menyentuh tubuhnya maupun istrinya sendiri. Subjek selalu merasa panik ketika subjek bangun dari tidurnya 
dikarenakan subjek harus bersiap untuk menghadapi musuhnya sehingga hal tersebut menjadi sebuah kebiasaan bagi subjek yang terbawa sampai saat ini walaupun subjek tidak berada di dalam medan perang. Subjek $Z$ juga memiliki keinginan untuk membunuh orang yang menyentuh dirinya.

\section{Tema 4: Rasa Bersalah}

\section{Tidak Merasa Bersalah}

Pada penelitian ini, dua subjek dari tiga subjek menyatakan bahwa tidak merasa bersalah dalam menghilangkan nyawa pelaku yang mengancam subjek saat bertugas. Kedua subjek tersebut menunjukkan bahwa subjek tidak merasa bersalah setelah melakukan penembakan, melainkan kedua subjek menyatakan bahwa subjek merasa bangga atas tindakannya karena subjek menilai bahwa pelaku sudah layak untuk mati. Subjek berpikir bahwa sudah menjadi sebuah risiko yang harus ditanggung oleh para musuh apabila musuh tersebut berhadapan dengan subjek begitu juga sebaliknya.

Merasa Bersalah

Pada penelitian ini, satu dari tiga subjek menyatakan bahwa subjek merasa bersalah dalam menghilangkan nyawa pelaku yang mengancam subjek saat bertugas. Salah satu subjek menunjukkan bahwa subjek merasa bersalah atas tindakannya terhadap pelaku seperti perasaan menyesal dan trauma yang dialami. Subjek juga menunjukkan ekspresi wajah penuh dengan penyesalan serta tangan yang gemetar ketika subjek harus mengingat kejadian tersebut. Subjek juga mengalami dilema dalam memilih perintah serta kewajiban sebagai anggota polisi namun disatu sisi subjek percaya bahwa dosa hukumnya untuk melakukan pembunuhan terhadap orang lain.

\section{Tema 5: Strategi Koping}

\section{Strategi Koping yang Berorientasi Pada Emosi}

Menjalankan Kewajiban

Subjek Y dan X memilih untuk berpikir bahwa subjek hanya menjalankan sebuah perintah dan kewajiban ketika melakukan pembunuhan tersebut. Subjek merasa sudah menjadi kewajiban yang harus dilaksanakan sebagai aparat penegak hukum untuk melawan para kelompok yang menginginkan NKRI hancur.

\section{Perilaku Menghindar}

Penyelesaian masalah atau koping emosi ini merupakan salah satu cara subjek untuk mengatasi perasaan bersalah setelah melakukan pembunuhan dilakukan oleh salah satu subjek yaitu subjek $\mathrm{Z}$ yang menyatakan bahwa subjek $\mathrm{Z}$ sudah menyiapkan diri untuk diambil nyawanya sewaktu-waktu. Subjek Z mengatakan bahwa setelah subjek melakukan pembunuhan, subjek akan menangani hal tersebut dengan cara meminum-minuman keras sehingga subjek dapat menghilangkan kejadian yang dilihat.

Mendekatkan Diri kepada Tuhan

Ketiga subjek yaitu Y, X, dan Z dalam penelitian ini memiliki kemiripan dalam menyelesaikan masalah setelah melakukan penembakan yaitu ketiga subjek melakukan pembersihan terhadap diri sendiri melalui upacara keagamaan, pelukatan, mendekatkan diri kepada Tuhan, berdoa dan bersyukur karena diberikan keselamatan.

\section{Strategi Koping yang Berorientasi Pada Masalah}

Strategi koping yang berorientasi pada masalah dilakukan oleh subjek Z. Subjek Z merasa tidak nyaman apabila subjek meneruskan untuk melakukan pekerjaan sebagai seorang sniper atau penembak, sehingga $Z$ meminta untuk dipindahtugaskan ke Bali di bagian Satlantas.

(Tabel 4. Perbandingan Kategori Pada Responden Terlampir).

\section{PEMBAHASAN DAN KESIMPULAN}

Berdasarkan penelitian yang telah dilakukan, diperoleh hasil dua dari ketiga subjek tidak merasa bersalah dan satu subjek merasa bersalah, serta terdapat dua strategi koping yaitu strategi koping yang berorientasi pada emosi dan berorientasi pada masalah yang digunakan oleh ketiga subjek dalam mengatasi perasaan yang dialami setelah menghilangkan nyawa orang lain saat bertugas. Hasil penelitian ini menunjukkan terdapat beberapa kategori yang dihasilkan pada ketiga subjek, yaitu proses kejadian, pasca kejadian, rasa bersalah, dan koping. Fokus utama dari hasil penelitian ini adalah rasa bersalah dan strategi koping.

Pada penelitian ini terdapat beberapa hal yang terjadi pada proses penghilangan nyawa saat bertugas yang dilakukan oleh ketiga subjek seperti latar belakang penembakan korban, jenis senjata yang digunakan, pemicu terjadinya penembakan, korban, dan kondisi saat penembakan. Latar belakang penembakan memiliki pengaruh terhadap subjek dalam melakukan penghilangan nyawa. Situasi dan kondisi yang penuh tekanan menuntut subjek untuk melakukan tindakan secara cepat. Hal tersebut sejalan dengan pernyataan Millett (dalam Murtono, 2009), mengenai faktor-faktor yang berpengaruh dalam pengambilan keputusan yaitu bahwa peran bagi seseorang yang mengambil keputusan perlu diperhatikan dalam menganalisis dan menginterpretasikan suatu masalah, terkait dengan keadaan subjek bahwa subjek dapat menganalisis masalah yang dialami seperti berada dalam keadaan yang mendesak tanpa bisa meminta pertolongan sehingga subjek dituntut untuk cepat dalam melakukan tindakan yang dibutuhkan.

Penembakan yang terjadi dipicu berbagai macam faktor yang dialami oleh ketiga subjek. Faktor-faktor pemicu terjadinya penembakan yaitu adanya ancaman terhadap subjek, melakukan perlawanan, dan pembalasan dendam. Hal yang dilakukan oleh ketiga subjek sesuai dengan yang tertera dalam Peraturan Kepala Kepolisian Negara Republik Indonesia Nomor 8 Tahun 2009, bahwa setiap petugas kepolisian diberikan perlindungan HAM. Korban dari penembakan tersebut merupakan kelompok-kelompok tertentu seperti separatis GAM, warga suku tertentu, serta kelompok sniper liar yang ingin memprovokasi keadaan disuatu wilayah. Hal tersebut sesuai dengan pernyataan Stephen Schafer (dalam Lilik Mulyadi, 2007) yang mengemukakan tipologi bentuk korban yaitu self victimizing victim bahwa korban kejahatan yang dilakukan sendiri atau kejahatan tanpa korban. Oleh karena itu tanggung jawab sepenuhnya terletak pada korban sekaligus sebagai pelaku kejahatan. 
Kondisi tersebut membuat ketiga subjek mengalami stres serta membuat subjek tidak dapat merasakan kenyamanan sama sekali saat berada disana. Hal tersebut sesuai dengan yang diungkapkan oleh Lazarus \& Folkman (dalam Taylor, 2012), dari salah satu tahap proses seseorang mengalami stres yaitu ketika seseorang tidak mampu mengatasi tekanan yang ada, maka berbagai ketegangan akan muncul, seperti ketegangan psikologis, perilaku dan fisik. Kondisi-kondisi tersebut menunjukkan bahwa HAM seseorang tidak berlaku dalam daerah konflik, Hal tersebut diungkapkan oleh Zunnuraeni (2014), bahwa penerapan hukum Hak Asasi Manusia (HAM) pada situasi konflik bersenjata memunculkan kemungkinan terjadinya pertentangan norma dengan hukum Humaniter Internasional.

Pada penelitian ini terdapat beberapa hal yang terjadi pada pasca kejadian penembakan terhadap ketiga subjek yang digambarkan menjadi reaksi subjek dan kondisi subjek setelah penembakan. Reaksi psikis ketiga subjek yang ditimbulkan yaitu berupa luapan emosi, perasaan jengkel, perasaan bangga, ingin membantai, dan sebagainya. Hal tersebut sesuai dengan hasil penelitian Aulia (2015), yang menyatakan bahwa sebagian pelaku pembunuhan merasakan efek kepuasan dan kebanggaan, sedangkan sebagian pelaku lainnya menunjukkan reaksi penyesalan serta mengalami indikasi gangguan pasca trauma. Selain reaksi psikis, subjek juga menunjukkan adanya reaksi fisik yaitu respon yang dialami oleh tubuh subjek setelah melewati kejadian penembakan. Beberapa reaksi fisik ditunjukkan oleh subjek seperti telinga yang berdenging dan tubuh yang tidak dapat disentuh. Menurut Sarason, Johnson, \& Siegel (dalam Taylor, 2012), kejadian yang negatif menyebabkan orang tertekan secara psikologis dan menimbulkan lebih banyak gejala fisik.

Pada penelitian ini, dua subjek dari tiga subjek menyatakan bahwa subjek pertama (Y) dan subjek kedua (X) tidak merasa bersalah setelah melakukan penembakan. Rasa tidak bersalah pada kedua subjek disebabkan karena subjek memiliki perasaan benci dan dendam sehingga subjek berpikir bahwa pelaku layak untuk mati. Pernyataan dari kedua subjek tidak memiliki kesesuaian dengan teori yang dikemukakan oleh Yakub (1997), bahwa akibat adanya rasa bersalah yaitu sikap mengutuk diri, bahwa rasa bersalah merangsang timbulnya sikap menyalahkan diri sendiri dalam bentuk gelisah, cemas, rasa rendah diri, rasa diri penuh kekurangan, pesimistis, rasa tidak aman, marah terhadap diri sendiri.

Salah satu subjek dari ketiga subjek menyatakan bahwa subjek merasa bersalah atas tindakannya. Subjek mengaku menyesal dan mengalami trauma setelah melakukan penembakan. Pernyataan subjek memiliki kesesuaian dengan hasil penelitian yang dilakukan oleh Aulia (2015), yaitu subjek yang mengalami dampak psikologis dengan adanya reaksi penyesalan pasca membunuh. Pada penelitian ini, terdapat berbagai bentuk penyelesaian masalah yang dilakukan oleh ketiga subjek seperti melakukan pembersihan terhadap diri sendiri melalui upacara keagamaan. Bentuk strategi koping ini dapat dikategorikan sebagai seeking meaning (berdoa), yang merupakan suatu proses individu mencari arti kegagalan yang dialami bagi dirinya sendiri dan mencoba mencari segi-segi yang menurutnya penting dalam hidupnya (Lazarus \& Folkman, dalam Taylor, 2012). Para subjek juga berpikir bahwa tindakan yang dilakukannya merupakan suatu bentuk perintah yang berasal dari pimpinan yang wajib untuk dijalankan. Sikap ini meliputi perasaan berkomitmen, respon positif terhadap tantangan, dan kontrol diri yang kuat. Keyakinan tersebut dapat membuat orang mampu menahan efek negatif dari stres (Taylor, 2012). Menurut Lazarus \& Folkman (dalam Taylor, 2012), bentuk dari strategi koping ini disebut escapism (menghindar) yaitu perilaku menghindari masalah yang dilakukan oleh individu dengan membayangkan dirinya berada dalam suatu situasi lain yang lebih menyenangkan, menghindari masalah dengan makan ataupun tidur, merokok, meminum-minuman keras, dan sebagainya. Strategi koping ini diterapkan oleh salah satu subjek dengan cara meminum-minuman keras sehingga membuat subjek dapat menghilangkan dan melupakan kejadian yang dilihat subjek.

Berdasarkan hasil penelitian, kesimpulan dari penelitian ini adalah dua dari tiga subjek tidak merasa bersalah, dan ketiga subjek memiliki strategi koping yang berbeda-beda, tetapi beberapa strategi yang dimiliki ketiga subjek hampir sama. Saran bagi penelitian ini adalah saran yang ditujukan kepada pihak kepolisian yang diharapkan dapat memberikan fasilitas untuk para petugas kepolisian yang menjalankan tugas terutama yang berada di daerah konflik berupa fasilitas kesehatan baik secara jasmani dan rohani khususnya terkait dengan pemberian konseling maupun terapi untuk petugas kepolisian yang mengalami trauma, serta pihak kepolisian yang bertugas diharapkan mampu untuk memberikan dukungan terhadap rekan kepolisian yang mengalami trauma untuk dapat bangkit kembali. Bagi peneliti selanjutnya diharapkan dapat mencari lebih banyak subjek agar hasil data yang diperoleh lebih akurat, lebih banyak meluangkan waktu dalam melakukan penggalian data, agar data yang dihasilkan lebih spesifik, serta mencari significant other, sehingga data yang diperoleh dapat mendukung pernyataan dari subjek dan data yang dihasilkan menjadi lebih akurat.

\section{DAFTAR PUSTAKA}

Aulia, Rina., Dewi, Rooswita Santia., Fauzia, Rahmi. (2015). Analisis Fenomenologi Eksistensi Narapidana Pelaku Pembunuhan Berencana di Lembaga Pemasyarakatan. Jurnal Ecospy, 2(1). Diakses dari http://ppjp.unlam.ac.id/journal/index.php/ecopsy/article/do wnload/512/427.

Candra, Asep. (2012). BKKBN: 2015, Laju Pertambahan Penduduk 1 Persen. Kompas. Diakses dari https://lifestyle.kompas.com/read/2012/09/27/07110483/B KKBN.2015..Laju.Pertambahan.Penduduk.1.Persen.

Coleman, Vernon. (1992). Rasa Salah: Mengapa Terjadi, Bagaimana Mengatasinya. Jakarta: Arcan Press.

Mulyadi, Lilik. (2007). Putusan Hakim dalam Hukum Acara Pidana. Bandung: PT. Citra Aditya Bakti.

Murtono, Imam. (2009). Teori Pengambilan Keputusan. Depok: Jurusan Manajemen Fakultas Ekonomi. Universitas Guna Darma.

Putri, I. A. Kencana J. S. (2017). Studi pendahuluan: Rasa Bersalah dan Strategi Koping Pada Petugas Kepolisian yang 


\section{RASA BERSALAH DAN STRATEGI KOPING PADA PETUGAS KEPOLISIAN}

Menghilangkan Nyawa Orang Lain Saat Sedang Bertugas. (Naskah tidak dipublikasikan). Program Studi Psikologi Fakultas Kedokteran Universitas Udayana Bali.

Subiyanto, Ibnu. (1993). Seri Diktat Kuliah "Metode Penelitian". Jakarta: Gunadarma.

Sugiyono. (2013). Metode Penelitian Kombinasi (Mixed Methods). Bandung: Alfabeta.

Taylor, S.E., Peplau, L.A., dan Sears, D.O. (2012). Psikologi Sosial. Edisi Kedua belas. Jakarta: Kencana Prenada Media Group

Yakub, B. (1997). Pastoral Konseling. (Jilid 2). Malang: Penerbit Gandum Mas.

Zunnuraeni. (2014). Penerapan Hak Asasi Manusia Pada Situasi Konflik Bersenjata. Jurnal Ilmu Hukum, 4(1). Diakses dari https://ejournal.unri.ac.id/index.php/JIH/article/view/2087.

Peraturan Perundang-Undangan

Peraturan Kepala Kepolisian Negara Kesatuan Republik Indonesia Nomor 8 Tahun 2009.

Peraturan Kepala Kepolisian Negara Republik Indonesia Nomor 1 Tahun 2009 tentang Penggunaan Kekuatan dalam Tindakan Kepolisian.

Undang-undang Nomor 2 tentang Kepolisian Negara Republik Indonesia Tahun 2002. 


\section{LAMPIRAN}

Tabel 1

perbandingan Kategori Pada Responden

\begin{tabular}{|c|c|c|c|c|c|c|c|c|c|}
\hline \multirow[b]{3}{*}{ Responden } & \multicolumn{9}{|c|}{ Kategori } \\
\hline & \multicolumn{4}{|c|}{ Proses Kejadian } & \multicolumn{2}{|c|}{ Pasca Kejadian } & \multicolumn{2}{|c|}{ Rasa Bersalah } & \multirow{2}{*}{\begin{tabular}{l}
\multicolumn{1}{c}{$\begin{array}{c}\text { Strategi } \\
\text { Koping }\end{array}$} \\
Penvelesaian \\
Masalah \\
Subjek
\end{tabular}} \\
\hline & $\begin{array}{l}\text { Latar } \\
\text { Belakang } \\
\text { Penembak } \\
\text { an Korban }\end{array}$ & $\begin{array}{l}\text { Pemicu } \\
\text { Terjadinya } \\
\text { Penembakan }\end{array}$ & Korban & $\begin{array}{l}\text { Kondisi Saat } \\
\text { Penembakan }\end{array}$ & $\begin{array}{l}\text { Reaksi } \\
\text { Subjek }\end{array}$ & $\begin{array}{l}\text { Kondisi } \\
\text { Subjek } \\
\text { Setelah } \\
\text { Penembak } \\
\text { an }\end{array}$ & $\begin{array}{l}\text { Tidak } \\
\text { merasa } \\
\text { bersalah }\end{array}$ & $\begin{array}{l}\text { Merasa } \\
\text { Bersalah }\end{array}$ & \\
\hline $\begin{array}{l}\text { Responden } \\
\text { Pertama } \\
\text { (Y) }\end{array}$ & $\begin{array}{l}\text { Penghada } \\
\text { ngan di } \\
\text { Jalan }\end{array}$ & $\begin{array}{l}\text { a. Perasaan } \\
\text { Terancam } \\
\text { b. Perlawanan } \\
\text { c. Balas } \\
\text { Dendam }\end{array}$ & $\begin{array}{l}\text { Separatis } \\
\text { GAM } \\
\text { (Gerakan } \\
\text { Aceh } \\
\text { Merdeka) }\end{array}$ & $\begin{array}{l}\text { a. Terkekang dan } \\
\text { Penuh Tekanan } \\
\text { b. Situasi dan } \\
\text { Kondisi yang } \\
\text { Menegangkan } \\
\text { c. HAM Tidak } \\
\text { Berlaku }\end{array}$ & $\begin{array}{c}\text { a. Reaksi } \\
\text { Psikis }\end{array}$ & - & $\begin{array}{l}\text { Tidak } \\
\text { Merasa } \\
\text { Bersalah }\end{array}$ & - & $\begin{array}{l}\text { a. Koping } \\
\text { yang } \\
\text { Berorientasi } \\
\text { Pada Emosi }\end{array}$ \\
\hline $\begin{array}{l}\text { Responden } \\
\text { Kedua (X) }\end{array}$ & $\begin{array}{l}\text { Pengepun } \\
\text { gan di } \\
\text { Tengah } \\
\text { Laut }\end{array}$ & $\begin{array}{l}\text { a. Perasaan } \\
\text { Terancam } \\
\text { b. Perlawanan } \\
\text { c. Balas } \\
\text { Dendam }\end{array}$ & $\begin{array}{l}\text { Warga } \\
\text { Suku } \\
\text { Tertentu }\end{array}$ & $\begin{array}{l}\text { a. Terkekang dan } \\
\text { Penuh Tekanan } \\
\text { b. Situasi dan } \\
\text { Kondisi yang } \\
\text { Menegangkan } \\
\text { c. HAM (Hak } \\
\text { Asasi Manusia) } \\
\text { Tidak Berlaku }\end{array}$ & $\begin{array}{l}\text { a. Reaksi } \\
\text { Psikis } \\
\text { b. Reaksi } \\
\text { Fisik }\end{array}$ & - & $\begin{array}{l}\text { Tidak } \\
\text { Merasa } \\
\text { Bersalah }\end{array}$ & - & $\begin{array}{l}\text { a. Koping } \\
\text { yang } \\
\text { Berorientasi } \\
\text { Pada Emosi }\end{array}$ \\
\hline $\begin{array}{l}\text { Responden } \\
\text { Ketiga (Z) }\end{array}$ & $\begin{array}{l}\text { Penvergap } \\
\text { an di } \\
\text { Perkampu } \\
\text { ngan }\end{array}$ & $\begin{array}{l}\text { a. Perasaan } \\
\text { Terancam } \\
\text { b. Perlawanan } \\
\text { c. Balas } \\
\text { Dendam }\end{array}$ & $\begin{array}{l}\text { Kelompo } \\
\text { k Shiper } \\
\text { Liar }\end{array}$ & $\begin{array}{l}\text { a. Terkekang dan } \\
\text { Penuh Tekanan } \\
\text { b. Situasi dan } \\
\text { Kondisi yang } \\
\text { Menegangkan }\end{array}$ & $\begin{array}{l}\text { a. Reaksi } \\
\text { Psikis } \\
\text { b. Reaksi } \\
\text { Fisik }\end{array}$ & $\begin{array}{l}\text { a. Mimpi } \\
\text { b. Kaget }\end{array}$ & - & $\begin{array}{l}\text { Merasa } \\
\text { Bersalah }\end{array}$ & $\begin{array}{l}\text { a. Koping } \\
\text { yang } \\
\text { Berorientasi } \\
\text { Pada Emosi } \\
\text { b. Koping } \\
\text { yang } \\
\text { Berorientasi } \\
\text { Pada } \\
\text { Masalah }\end{array}$ \\
\hline
\end{tabular}

